\title{
Pengelolaan Sudut Baca Dalam Menumbuhkan Minat Baca Peserta Didik Kelas III SD Negeri 04 Popayato Barat
}

\author{
Karsum Sam Mantu \\ SD Negeri 04 Popayato Barat \\ karsumsam@gmail.com
}

Received: 17 March 2021; Revised: 16 June 2021; Accepted: 28 August 2021
DOI: $\underline{\text { http://dx.doi.org/10.37905/aksara.7.3.877-884.2021 }}$

\begin{abstract}
Abstrak
Penelitian ini membahas tentang upaya guru dalam pengelolaan sudut baca untuk menumbuhkan minat baca peserta didik kelas III SD Negeri 04 Popayato Barat. Penelitian ini menggunakan rancangan penelitian kualitatif yaitu dimana peneliti berperan secara langsung sebagai perencana, pelaksanaan, pengumpulan data, menganalisis data dan sekaligus pelapor data. Pengumpulan data di lakukan dengan observasi, teknik wawancara langsung dan dokumentasi. Peneliti menemukan bahwasanya upaya guru dalam pemanfaatan sudut baca untuk menumbuhkan minat baca peserta didik yaitu, (1). Mendorong anak bercerita tentang apa yang telah dibacanya, (2). Tukar buku dengan teman, (3). Menyediakan buku yang menarik minat baca peserta didik, (4). Menyediakan waktu membaca, dan (5). Memberikan hadiah. Kendala dalam menumbuhkan minat baca peserta didik tersebut ialah, minimnya ruangan kelas, kurangnya variasi buku atau keterbatasan buku dan terdapat peserta didik yang tidak suka membaca. Adapun untuk mengatasi kendala tersebut yaitu membuat dekorasi pojok baca yang rapi dan indah, mengusulkan pihak sekolah menaikan anggaran perpustakaan, dan memberikan motivasi serta dukungan. Hasil dari penelitian ini bahwasannya Adanya sudut baca membuat peserta didik merasa senang dan lebih giat dalam membaca.
\end{abstract}

Kata Kunci: Sudut Baca, Minat Baca

\section{PENDAHULUAN}

Membaca merupakan langkah awal bagi seseorang untuk menuju ke keterampilan berbahasa lainnya. Kegiatan membaca perlu ditingkatkan sejak usia dini agar peserta didik atau peserta didik dapat terbiasa dengan aktifitas membaca. Dengan membaca berarti kita menerjemahkan, menginterprestasikan tanda-tanda atau lambanglambang dalam bahasa yang dipahami oleh pembaca. Konsep pendidikan yang dianut di negara kita adalah konsep pendidkan sepanjang hayat (life long education). Hal ini sejalan dengan kewajiban setiap manusia untuk selalu belajar sejak dilahirkan sampai akhir hayatnya.

Pentingnya membaca dalam dunia akademik, pemerintah memiliki terobosan yaitu melalui peraturan mentri pendidikan dan kebudayaan (Permendikbud) Nomor 23 Tahun 2015 tentang Penumbuhan Budi Pekerti luhur kepada peserta didik dengan mengembangkan Gerakan Literasi Sekolah (GLS). Menurut Abidin (2017:279) Gerakan Literasi Sekolah (GLS) adalah gerakan sosial dengan dukungan dari berbagai elemen 
yang saling berkolaborasi. Upaya yang ingin ditempuh adalah menjadikan peserta didik mempunyai kebiasaan membaca dengan adanya program GLS tersebut.

Banyak sekolah yang mulai menggiatkan Gerakan Literasi Sekolah, terutama dengan mengadakan sudut baca/pojok baca. Dengan adanya sudut baca di setiap sekolah sangat efektif untuk menumbuhkan minat peserta didik untuk membaca. Kegiatan ini bisa dilakukan 15 menit sebelum pembelajaran dimulai atau saat jam istirahat, peserta didik dapat mendatangi sudut baca di sekolah masing-masing, dengan penataan rapi dan menarik banyak peserta didik senang dan seringkali mendatangi sudut baca tersebut.

Kebiasaan membaca tidak dapat muncul dengan sendirinya tanpa adanya suatu dorongan yang kuat dari dalam diri. Hal tersebut menunjukan bahwa kegiatan membaca harus dikembangkan dengan tujuan untuk menciptakan siswa yang memiliki budaya membaca. Budaya mmbaca dan menulis harus ditanamkan pada anak usia sekolah dini. Kegiatan ini dapat dilakukan dalam pendidikan maupun diluar pendidikan

Minat baca sangat diperlukan untuk memudahkan peserta didik dalam meningkatkan prestasi belajar mereka. Dengan membaca pembelajaran akan sangat bermakna, meningkatkan mutu pembelajaran dan setiap kegiatan membaca akan terasa menyenangkan tanpa adanya paksaan. Kegiatan membaca tentunya memberikan dampak positif dalam meningkatkan keterampilan menulis narasi, mengembangkan ide yang mempermudah peserta diidk dalam menyusun sebuah cerita Untuk menumbuhkan minat baca peserta didik, pihak sekolah perlu memfasilitasi salah satunya adalah dengan cara membuat sudut baca disetiap kelas. Sudut baca bisa diisi dengan buku-buku sesuai dengan kebutuhan setiap tingkatan kelas. Philomena (2018:93) Ketersediaan ruang baca adalah hal penting untuk merangsang peserta didik untuk membaca

Keberadaan sudut baca dilingkungan sekolah membantu dalam menumbuhkan budaya literasi pada peserta didik disekolah dan adanya sudut baca di lingkungan sekolah memberikan warna baru atau suasana baru pada peserta didik sehingga peserta didik termotivasi untuk membaca

Minat membaca peserta didik di Sekolah Dasar tentu tidak terlepas dari faktorfaktor yang mempengaruhi atau penghambat minatnya membaca. Sama halnya dengan peserta didik kelas III SD Negeri 04 Popayato Barat yang merupakan kelas rendah. Kurangnya minat ini dapat terlihat saat pagi hari, bahwasannya setiap pagi sebelum memulai pembelajaran peserta didik diminta terlebih dahulu membaca buku yang terdapat di pojok baca tersebut. Hal ini dapat dilihat dari aktivitas peserta didik, peserta didik lebih suka bermain daripada menyempatkan diri untuk membaca buku. Peserta didik akan membaca buku ketika guru menugaskan untuk membaca. Hal tersebut menunjukkan bahwa minat baca peserta didik dalam memanfaatkan sudut baca belum digunakan sebagaimana mestinya

Penyebab rendahnya minat baca bagi peserta didik diantaranya 1) Masih rendahnya kemahiran membaca peserta didik, 2) Banyaknya jenis hiburan dan tayangan di TV yang mengalihkan perhatian anak-anak dari buku, dan 3) Minimnya koleksi buku diperpustakaan yang kurang memadai tumbuh kembangnya minat baca peserta didik

Berdasarkan uraian di atas, maka rumusan masalah pada penelitian adalah: bagaimana upaya guru mengoptimalkan sudut baca dalam menumbuhkan minat baca peserta didik kelas III SD Negeri 04 Popyato Barat? 
Adapun tujuannya adalah untuk mendeskripsikan upaya guru dalam mengoptimalkan sudut baca untuk menumbuhkan minat baca peserta didik kelas III SD Negeri 04 Popayato Barat

\section{METODE PENELITIAN}

Jenis penelitian ini adalah penelitian kualitatif dengan menggunakan pendekatan secara deskriptif kualitatif. Penelitian deskriptif adalah metode penelitian yang berusaha menggambarkan objek atau subjek yang diteliti sesuai dengan apa adanya, dengan tujuan menggambarkan secara sistematis, fakta dan karakteristik objek yang diteliti secara tepat.

Setting Penelitian ini dilaksanakan di SD Negeri 04 Popayato Barat. Alasan peneliti memilih karena peneliti bertugas di SD Negeri 04 Popayato Barat dan sudah terdapat sudut baca, terutama di kelas III.

\section{Interview}

Dalam pengumpulan data dilakukan dengan beberapa cara antara lain adalah :

Teknik interview menurut Mardalis adalah suatu proses tanya jawab lisan antara dua orang atau lebih berhadapan secara fisik, yang satu dapat melihat muka yang lain dan mendengarkan.

\section{Observasi (pengamatan)}

Observasi adalah pengumpulan data yang dilakukan dengan cara melihat dengan mengamati secara langsung objek untuk melihat dengan dekat kegiatan yang dilakukan objek tersebut. Kegiatan observasi meliputi pengamatan dan pencatatan secara sistematis kejadian-kejadian, pelaku, maupun objek yang dilihat serta hal-hal lain diperlukan dalam penelitian yang sedang dilakukan.

\section{Dokumentasi}

Dokumentasi adalah ditunjukan untuk memperoleh data langsung dari tempat penelitian, meliput buku-buku yang relevan, peraturan-peraturan, laporan, kegiatan, serta hal-hal yang relevan dengan eksperimen itu.

Teknik yang biasanya digunakan para peneliti untuk mengumpulkan data adalah wawancara mendalam, observasi, dan pengumpulan dokumen (Afrizal, 2017)

1) Wawancara yaitu suatu cara mengumpulkan data atau informasi dengan cara langsung bertatap muka dengan informan, dengan maksud mendapatkan gambaran lengkap tentang topik yang diteliti

2) Observasi peneliti untuk mengetahui sesuatu yang sedang terjadi atau yang sedang dilakukan merasa perlu untuk melihat sendiri, mendengarkan sendiri atau merasakan sendiri.

3) Dokumentasi, para peneliti mengumpulkan bahan tertulis seperti berita di media, notulen-notulen rapat, surat menyurat dan laporan-laporan untuk mencari informasi yang diperlukan

Dalam penelitian ini, mengunakan teknik penelitian kualitatif. Data yang telah di kumpulkan baik melalui wawancara mendalam, pengamatan maupun pencatatan dokumen di kumpulkan dan di analisa dengan membuat penafsiran. Proses analisis data dalam penelitian ini atau dalam menggunakan metode kualitatif yakni di lakukan pada waktu bersamaan dengan proses pengumpulan data berlangsung.

Adapun menurut (Huberman \& Miiles, 1992:2) analisis data dapat dilakukan dengan tiga alur, yakni : 


\section{Penyajian Data}

Data penelitian kualitatif, dimana penyajian data dilakukan dalam bentuk uraian singkat, bagan, yang paling sering digunakan untuk menyajikan data dalam penelitian kualitatif adalah teks yang bersifat naratif.

2. Reduksi Data

Reduksi data merupakan proses seleksi pemfokusan, penyederhanaan data yang kasar yang muncul dari catatan tertulis di lapangan yang mengatur data sedemikian rupa. Mereduksi data dengan cara merangkum, memilih hal-hal pokok, memfokuskan hal-hal yang penting dan membuang hal-hal yang dianggap kurang penting.

3.Penarikan Kesimpulan

Penarikan kesimpulan yaitu suatu kegiatan yang dikonfigurasi secara utuh. Kesimpulan-kesimpulan juga diverifikasi selama penelitian berlangsung. Verifikasi itu mungkin sesingkat pemikiran kembali dari peneliti selama menulis, suatu tinjauan ulang pada catatan-catatan lapangan.

\section{PEMBAHASAN}

\section{Upaya guru kelas III dalam pemanfaatan sudut baca untuk menumbuhkan minat baca peserta didik}

Sudut baca merupakan sebuah ruangan yang terletak disudut kelas yang dilengkapi dengan koleksi buku dan berperan sebagai perpanjangan fungsi perpustakaan. Melalui sudut baca peserta didik dilatih untuk membiasakan membaca buku, sehingga menjadikan peserta didik gemar membaca. Sudut baca didesain dengan tampilan yang menarik sehingga peserta didik lebih berminat untuk membaca buku tersebu (Kemendikbud, 2016:13) Adanya sudut baca peserta didik lebih mudah untuk membaca buku yang mereka inginkan tanpa harus berkunjung ke perpustakaan terlebih dahulu.

Upaya guru dalam pemanfaatan sudut baca di kelas III SD Negeri 04 Popayato Barat mendapatkan hasil yang cukup memuaskan. Peserta didik menjadi lebih gemar dalam membaca, peserta didik juga akan membaca buku tanpa diminta oleh guru maupun membaca disaat ada tugas saja. Banyaknya upaya yang telah dilakukan oleh guru membuahkan hasil dalam proses menumbuhkan minat baca peserta didik

Setelah dilakukannya penelitian, peneliti menemukan temuan tentang bagaimana upaya guru dalam pemanfaatan sudut baca untuk menumbuhkan minat baca siswa di kelas III SD Negeri 04 Popayato Barat. Maka ada beberapa temuan penelitian yaitu sebagai berikut:

a) Mendorong anak bercerita tentang apa yang telah dibacanya

Upaya guru dalam menumbuhkan minat baca peserta didik dengan berbagai cara telah ia lakukan termasuk mendorong anak untuk menceritakan kembali isi dari bacaan yang telah dibacanya. Untuk melihat sejauh mana pemahaman anak tentang pengetahuan yang telah dibaca tersebut

Peserta didik sangat perlu dorongan berupa support maupun arahan dari guru untuk lebih gemar dalam membaca, membaca buku tidak sekedar habis dibaca lalu ditutup saja. Jadi dalam menumbuhkan minat baca guru tidak hanya meminta peserta didik membaca buku lalu menutupnya kembali, namun peserta didik harus diminta berani untuk menceritakan kembali isi buku yang telah ia baca. Dengan begitu peserta didik akan sunguh-sungguh dalam membaca dan mengingat apa yang telah ia baca. 


\section{b) Tukar buku dengan teman}

Salah satu upaya untuk menumbuhkan minat baca peserta didik yaitu dengan menukarkan buku yang telah ia baca dengan buku teman maupun kerabat. Berdasarkan hasil observasi yang telah dilakukan bahwa minat baca peserta didkk tumbuh setelah menukarkan buku dengan temanya. Hal tersebut dikarenakan peserta didik menjadi lebih berpeluang untuk membaca buku yang telah diinginkan dan peserta didik lebih kaya akan pengetahuan

c) Menyediakan buku yang menarik minat baca siswa

Pada dasarnya peserta didik tingkat Sekolah Dasar masih berada difase mudah bosan, dengan begitu peserta didik perlu banyak referensi buku yang berbeda-beda untuk dibacanya. Tidak hanya buku cerita saja tetapi juga harus memuat buku pembelajaran

d) Menyediakan waktu membaca

Tanda minat baca peserta didik telah tumbuh ialah dengan melihat bahwa peserta didik membaca tanpa diminta, dan peserta didik meluangkan waktu untuk membaca disaat waktu luang

Sebagaimana yang didapat oleh penulis ketika penelitian di SD negeri 04 Popayato Barat, peneliti menyimpulkan bahwa ditemukannya peserta didik yang sedang membaca disaat jam kosong maupun jam istirahat. Oleh karena itu usaha guru dalam menumbuhkan minat baca peserta didik dengan memanfaatkan sudut baca mampu dijalankan oleh peserta didik

e) Memberi Hadiah

Memberikan hadiah atau reward sebagai tanda suatu penghargaan atas prestasi yang telah dimliki menjadi kebahagian tersendiri untuk peserta didik Sebagaimana yang didapat oleh penulis ketika melakukan penelitian di SD Negeri 04 Popayato Barat, peneliti menyimpulkan dari temuan-temuannya bahwa guru selalu berupaya memberikan hadiah kepada peserta didik, agar anak selalu bersemangat dalam membaca buku

\section{Kendala-kendala dalam menumbuhkan minat baca dengan memanfaatkan sudut baca di SD Negeri 04 Popayato Barat}

a) Minimnya ruangan kelas

Minimnya ruangan kelas menjadi salah satu kendala dalam pemanfaatan sudut baca di SD Negeri 04 Popayato Barat. Karena sebaiknya di dalam penataan ruang harus merancang denah penempatan dengan memperhatikan pencahayaan, sirkulasi udara, keamanan dan kenyamanan siswa.

b) Kurangnya variasi buku atau keterbatasan buku

Kurangnya minat baca pada anak bisa juga karena tidak ada atau kurangnya sarana untuk kegiatan tersebut. Dirumah orang tua mungkin kurang menyediakan bukubuku bacaan berkualitas sehingga anak tak diperkenalkan dengan kegiatan membaca.

c) Peserta didik yang tidak suka membaca

Lamb dan Arnold (dalam Rahim, 2005:17) mengatakan bahwa walaupun tidak mempunyai gangguan pada alat penglihatannya beberapa anak mengalami kesukaran belajar membaca. Hal itu dapat terjadi karena belum berkembangnya kemampuan mereka dalam membedakan simbol-simbol cetakan, seperti hurufhuruf,angka-angka, dan kata-kata, misalnya anak belum bisa membedakan $b$, p, dan d. perbedan pendengaran (auditory discrimination) adalah kemampuan mendengarkan kemiripan 
dan perbedaan bunyi bahasa sebagai faktor penting dalam menentukan kesiapan membaca anak.

\section{Upaya mengatasi kendala dalam menumbuhkan minat baca peserta didik dengan memanfaatkan sudut baca}

a) Mendekorasi sudut baca dengan rapi dan indah

Sudut baca didesain dengan tampilan yang menarik sehingga peserta didik lebih berminat untuk membaca buku tersebut, bahan dasar yang digunakan untuk membuat sudut baca menggunakan alat dan bahan yang sederhana sehingga tidak membutuhkan dana yang terlalu besar. Bahan dasar yang digunakan yaitu meja yang tidak terpakai yang ada di belakang kelas. Meja tersebut dapat dimanfaatkan sebagai pojok baca untuk meminimalisir pengeluaran dan memanfaatkan bahan yang tidak terpakai di kelas. (Muhammad Hamid, 2015, hal. 5)

b) Pihak sekolah menaikan anggaran perpustakaan

Sebagai solusi atau permasalahan penyebab rendahnya minat baca terutama pada anak dan remaja ini perlu dilakukan kerja sama antara pihak-pihak terkait seperti pemerintah, para pendidik, juga orang tua.

c) Memberikan motivasi dan dorongan

Anak-anak usia dini sangat membutuhkan dorongan dan semangat dari orang tua maupun guru mereka. Berikan motivasi kepada anak dan jelaskan kepada mereka pentingnya kegiatan ini, sehingga mereka akan semakin paham akan manfaat membaca.

\section{KESIMPULAN}

Dari beberapa permasalahan yang peneliti kemukakan, maka dapat diambil beberapa kesimpulkan antara lain:

1. Upaya guru dalam memanfaatkan sudut baca untuk menumbuhkan minat baca peserta didik kelas III dengan berbagai cara yaitu yang pertama dengan mendorong anak bercerita tentang apa yang telah dibacanya, setelah bercerita anak diminta untuk tukar buku dengan teman, setelah itu guru menyediakan buku yang menarik minat baca peserta didik, lalu menyediakan waktu membaca dan yang terakhir yaitu memberikan reward atau memberikan hadiah.

2. Kendala yang dihadapi guru dalam menumbuhkan minat baca peserta didik dengan memanfaatkan sudut baca adalah minimnya ruangan kelas, kurangnya variasi buku atau keterbatasan buku, dan peserta didik yang tidak suka membaca.

3. Upaya untuk mengatasi kendala dalam menumbuhkan minat baca dengan memanfaatkan sudut baca adalah dengan mendekorasi sudut baca dengan rapi dan indah agar ketidaknyamanan peserta didik bisa tertutupi, menaikan anggaran perpustakaan, dan memberikan motivasi serta dukungan kepada peserta didik tersebut

\section{SARAN}

Berdasarkan hasil penelitian tentang pengelolaan sudut baca di lingkungan sekolah dalam menumbuhkan budaya literasi pada peserta didik SD Negeri 04 Popayato Barat maka peneliti menyarangkan yaitu:

1. Memberikan fasilitas yang memadai terutama koleksi yang ada disudut baca perlu diperbarui satu bulan sekali.

2. Memajang koleksi buku seperti buku komik atau buku cerita. 
3. Peserta didik perlu menjaga kebersihan pada area sudut baca tidak membuang sampah agar pengujung nyaman pada saat berkunjung disudut baca

4. Menata ruangan sudut baca sebaik-baiknya agar dapat menarik daya tarik peserta didik untuk lebih rajin berkunjung ke sudut baca.

5. Mengganti bahan bacaan yang ada di sudut baca tiap bulan dengan buku yang berbeda-beda.

\section{DAFTAR PUSTAKA}

Abidin, Yunus. Dkk. 2017. Pembelajaran Literasi. Jakarta. Bumi Aksara.

Afrizal. 2017. Metode Penelitian Kualitatif Sebuah Upaya Mendukung Pengguna Penelitian Kualitatif Dalam Berbagai Disiplin Ilmu. Depok: Rajawali Pers

Antoro, B. 2017. Gerakan Literasi Sekolah Dari Pucuk Hingga Akar Sebuah Refleksi. Jakarta: Direktorat jenderal pendidikan dasar dan menengah kementrian pendidikan dan kebudayaan

Atmazaki. 2017. Panduan Praktis Gerakan Literasi Sekolah. Jakarta: Direktorat jenderal pendidikan dasar dan menengah kementrian pendidikan dan kebudayaan

Dalman. 2017. Keterampilan Membaca. Jakarta: Rajawali pers

Faradina, N. 2017. Pengaruh Program Gerakan Literasi Sekolah Terhadap Minat Baca Siswa Di SD Islam Terpadu Muhammadiyah An-Najah Jatinom Klaten. Jurnal hanata widya Volume 6 Nomor 8

Farida Rahim. 2005. Pengajaran Membaca di Sekolah Dasar. Jakarta: Bumi Aksara

Hartyatni, M. S. 2018. Membangun Budaya Baca Melalui Pengelolaan Media Sudut Baca Kelas Dengan "12345". Jurnal pemikiran dan pengembangan SD, Volume 6, Nomor 1 April

Maruroh, R. V. 2017. Analisis Pemanfaatan Sudut Baca Di Lingkungan Sekolah Guna Menumbuhkan Budaya Literasi Pada Siswa Di SD Negri Polomarto . Purwekerto: Universitas Muhammadiyah Purwekerto

Meliawati. 2016. Pemahaman Dasar Membaca. Yogyakarta: Deepublish

K.C Taufani. 2009. Menginstal Minat Baca Siswa. Bandung: PT Globalindo Universal Multikreasi

Kemendikbud. 2015. Permendikbud No 23 Tahun 2015 Penumbuhan Budi Pekerti. Jakarta: Kemendikbud

Kementrian Pendidikan Dan Kebudayaan. 2016. Panduan Pemanfaatan Dan Pengembangan Sudut Baca Kelas Dan Area Baca Sekolah Untuk Meningkatkan Mutu Pembelajaran Di Sekolah Dasar. Jakarta: Direktorat jenderal pendidikan dasar dan menengah Kementrian pendidikan dan kebudayaan 
Tampubolon, D.P. 1991. Kemampuan Membaca: Teknik Membaca Efektif dan Efisien. Bandung: Angkasa

Sugiyono. 2013. Metode Penelitian Kuantitatif Dan Kualitatif Dan R\&D. Bandung: 